\title{
Factors Affecting the Adoption of Improved Planting Materials by Cassava Farmers in Ekiti State, Nigeria
}

\author{
Adetule F. S., Owoeye R. S., Sekumade Adelomo Bosede \\ Department of Agricultural Economics and Extension Services, Ekiti State University, Ado-Ekiti, Nigeria
}

Email address:

rufus.owoeye@eksu.edu.ng (Owoeye R. S.), funsoadetule@gmail.com (Adetule F. S.)

\section{To cite this article:}

Adetule F. S., Owoeye R. S., Sekumade Adelomo Bosede. Factors Affecting the Adoption of Improved Planting Materials by Cassava Farmers in Ekiti State, Nigeria. International Journal of Sustainable Development Research. Vol. 3, No. 3, 2017, pp. $27-31$. doi: $10.11648 /$ j.jijsdr.20170303.11

Received: July 3, 2017; Accepted: July 18, 2017; Published: September 12, 2017

\begin{abstract}
The study was carried out to examine the factors affecting the adoption of improved planting materials by cassava farmers in Ekiti State, Nigeria. One hundred and eighty cassava farmers were selected through random sampling procedure. Data were collected from them using a set of well-structured questionnaire. Data collected were analyzed using descriptive statistics and econometric method of data analysis, using binary logistic regression model to analyze the probability of adoption of improved cassava planting materials. The study revealed that $59.1 \%$ of the respondents were above 50 years old while majority $(85.1 \%)$ were male, $66.9 \%$ were married. The result reported further $51.9 \%$ had formal education while $48.1 \%$ did not attend any formal school. Majority of the sampled farmers $(66.3 \%)$ took farming as major occupation as $75.7 \%$ of the farmers had less than one hectare as their farm size. In having access to extension service, $50.8 \%$ of the respondents claimed to have been visited while $49.2 \%$ did not. Their sources of awareness indicate that majority (37.6\%), got aware of innovation on radio, closely followed by $28.2 \%$ from extension agents and $26.4 \%$ from other farmers who are either colleagues or farm neighbour. The study of adoption level indicates that majority $(55.8 \%)$ had finally adopted, $19.3 \%$ are on trial stage, $7.2 \%$ are still evaluating, $13.8 \%$ had shown interest in knowing more about improved varieties while only $3.9 \%$ said truly they were aware that improved cassava cultivars was available in town. The result of logit regression $\left(\mathrm{R}^{2}\right)$ of 0.65 is high meaning that about $65 \%$ of adoption of improved cassava planting material is explained by the explanatory variables. The result further reported that output and farming experience were statistically significant at $1 \%$ while farm size and access to extension services were statistically significant at $5 \%$. Also, age, level of education and access to credit were statistically significant at $10 \%$. It implies that the statistically significant variables greatly influenced the adoption of improved cassava planting materials in the study area. Cassava production is however fraught with many problems with insufficient labour being the highest $(34.2 \%$ ) followed by pest and diseases $23.8 \%$, others are high cost of labour $16.6 \%$, lack of credit $10.0 \%$, low extension contacts $8.8 \%$ marketing problem $5.0 \%$ and others.
\end{abstract}

Keywords: Adoption, Improved Planting Materials, Cassava Farmers, Binary Logistic Regression

\section{Introduction}

Nigeria is an agrarian nation as over $56 \%$ of its population engaged in one form of agricultural activities or the other [1]. Agriculture provides the bulk of employment, income and food for the populace. It also provided raw materials for the agro allied industries as well as the market for industrial goods. Before independence, Nigeria's economy was largely sustained through export trade in agricultural commodities such as cocoa, groundnut, rubber, cotton, palm oil and palm kernel which accounted for over $60 \%$ of Nigeria's export earnings. Apart from this, the sector also accounted for the largest proportion of the gross domestic product (GDP) [2]

The situation suddenly changed in the early 1970's when there was extensive exploitation, production and exportation of petroleum and its products in Nigeria. The relegation of agricultural sector had manifested itself in rising food prices, high food import bills, huge malnutrition and diseases occasioned by supply - demand disequilibria and a drastic decline in the share of agriculture in Nigeria's Gross Domestic Product (GDP). The agricultural sector's contribution to the GDP over the years has been on the decline. It has dropped from $62.5 \%$ averagely in the $1960-$ 
1964 period, $40.79 \%$ in the $2000-2002$ period [3].

To reverse this trend of poor performance of the agricultural sector, Nigeria is currently preoccupied with the challenges of diversifying the structure of its economy and over the years, there have been different agricultural policies targeted at improving the performance of the agricultural sector and reviving export trade in semi - processed agricultural commodities. Chiefly among these policies is the diversification of the source of foreign exchange earnings through agricultural export arising from adoption of appropriate technological innovations in food production and distribution.

Cassava (Manihot esculenta crantz) is a major food in Nigeria, Africa's most populous country and the world's largest producer of cassava (International Institute of Tropical Agriculture, 1998). [4] stated that Nigeria is the world's largest producer; its cassava transformation is the most advanced in Africa. However, the scope for increasing the use of cassava in Nigeria's industries is to a large extent, determined by the development of an efficient and well integrated production and marketing system to assure a steady supply of cassava products of stable, high quality standards and appropriate price and of specific properties price required by domestic industries and export markets.

In Africa, cassava is gradually being transformed from a famine reserve commodity and rural food staple to a cash crop for urban consumption [5].

Cassava has become very popular as a food and cash crop and is replacing yam and other traditional staples in both rural and urban centers [4]. Cassava is important, not only as a food crop but even more as a major source of income for rural household. [2] emphasized that with an annual production of over 34 million tons of tuberous roots, Nigeria is currently the largest producer of cassava in the world and is consumed in many processed forms in the country. It is used in the industries as livestock feed; it is also gradually increasing especially as import substitution. It has thus become prominent in the industrial sector of the economy.

As a food crop, cassava has some inherent characteristics, which make it attractive especially, to smallholder farmers in Nigeria. First, it is rich in carbohydrates especially starch and consequently has a multiplicity of end users. Secondly, it is available all the year round making it preferable to other more seasonal crops such as grains, peas and beans and other crops for food security [6]. Compared to grains, cassava is more tolerant to low soil fertility and more resistant to drought, pests and diseases. Furthermore; its roots are more storable in the ground for months after maturity. These attributes combined with other socioeconomic considerations are therefore what International Fund for Agricultural Development (IFAD) has recognized in the crop as lending itself to a commodity - based to poverty alleviation [7].

In Nigeria, agricultural production and productivity are being hindered by some problems. These problems include the following inadequate credit, labour, output (farm output), non-adoption of improved technology as a result of low income, low purchasing power of farmers to purchase agrochemicals and other inputs that can enhance the productivity, inadequate information on modern and improved cassava varieties that can improve production output and some socio - economic factors. There is need therefore to carry out a comprehensive study on factors affecting the adoption of improved cassava varieties in the study area with the view of coming out with recommendations based on the study that will assist in ameliorating the declining in production. Hence the study aims to identify the information sources by which farmers become aware of improved technology; determine the levels of adoption of improved planting materials by the respondents; examine the probability of adoption of improved planting materials by cassava farmers; and identify the various problems faced by cassava farmers in the study area.

\section{Research Method}

\subsection{Area of the Study}

This study was carried out in Ekiti State. Ekiti State is in the southwestern Geo - political zone of Nigeria. It was calved out of the old Ondo - State on October $1^{\text {st, }} 1996$. It is located between longitude $7^{0} 45^{\prime}$ and " 5 " 45 " " East of the East of the Greenwich meridian and latitudes $7^{0} 45^{\prime}$ East and $8^{0} 5$, North of the equator. It comprises sixteen (16) local government areas with Ado - Ekiti as the State capital. Ekiti State is bounded in the North by Kwara and Kogi States, in the south by Ondo - State, in the west by Osun State and in the East by Ondo - State. Ekiti State has a means annual rainfall of about $1400 \mathrm{~mm}$ and a mean annual temperature of about $27^{\circ} \mathrm{C}$. Its vegetation ranges from rain forest in the south to guinea savannah in the North with soil largely rich in organic minerals thereby making the State a major producer of tree and food crops. According to 2006 population and housing census, the State has 2.5 million people and is made up of predominantly of the Yoruba ethnic groups with a few other ethnic groups that have settled in the state. The indigenous populations are peasant farmers who live in rural community settings. They are closely related in tradition and culture and speak the same language with minor dialect differences. For this reason, Ekiti State has been described as unique in composition as it is the only state in Nigeria with homogenous ethnic group [8]. The occupation of the people is farming with food crops like yam, maize, cassava, rice and cocoyam e.t.c. and some cash crops such as cocoa, kola nut, cashew and oil palm with reasonable percentage of them engaging in other forms of occupation such as trading, weaving and hand craft etc. hence Ekiti is predominantly agrarian in nature.

\subsection{Sampling Procedure and Sample Size}

The study made use of ADP Division in the State which is made up of Ikole as ADP State headquarters and two zonal headquarters which comprises of eight Cells (Local Government) each. Zone one has Aramoko has Zonal headquarter with the following cells Ekiti - West, Efon, Ekiti South West, Irepodun / Ifelodun, Ijero, Ido/ Osi, Moba and 
Ilejemeje while Zone two has Ikere as Zonal headquarter and it comprises of Oye, Ikole, Ekiti East, Emure, Ise / Orun, Ado and Gbonyin Ceils (Local Government). Three Cells were selected from each of the two zones. From zone one, Ekiti West, Irepodun / Ifelodun and Moba Cells were selected while from zone two Ikole, Gbonyin and Ekiti East were selected. The choice of these Cells is based on the on the fact that, the areas have large population of cassava farmers. Three towns / villages were randomly selected without replacement from each of the Ceils making eighteen communities while TEN respondents were randomly selected to make a sample size of 180 respondents.

\subsection{Method of Data Analysis}

\subsubsection{Binary Logistic Regression Model}

In making the decision whether or not to adopt a given technology, it may be assumed that the producer weighs up the marginal advantages and disadvantages of the adoption. The parameters of this decision are not usually observable but can be defined as a latent variable $\mathrm{Y}^{*}$, which is an unobservable index of the willingness of each producer to adopt the recommended farming practices and which can be related to set of explanatory variables $X_{1}-X_{n}$.

The binary logistic regression applied maximum likelihood estimate by transforming the dependent variable into logit (the natural $\log$ ) of the odds of the dependent variables occurring.

The observed pattern of adoption can then be described by a dummy variable, $y$, such that $y_{i}=1$ if farmer $i$ has adopted or $y_{i}=0$ if farmer $i$ has not adopted. That is, logistic regression is a technique for analyzing problems in which there are one or more independent variables which determine an outcome that is measured with a dichotomous variable in which there are only two possible outcomes, (True $=1$ or False $=0$ ).

In logistic regression, the dependent variable is the probability that an event will occur.

The logistic model is written as:

$$
P_{i}=\frac{1}{1+\ell^{-z_{i}}}
$$

Where;

$$
Z_{i}=B_{0}+B_{1} X_{1}+B_{1} X_{2} \ldots \ldots \ldots \ldots \ldots \ldots \ldots \ldots B_{n}+n
$$

The logistic equation can be rearranged by converting the probability into log odds of logit

$$
\begin{aligned}
\operatorname{Logit}(P)=B_{0} & +B_{1} X_{1}+B_{2} X_{2}+B_{3} X_{3} \\
& +\cdots \ldots \ldots \ldots \ldots \ldots B_{n}+n+U_{i}
\end{aligned}
$$

Where $\mathrm{P}$ is the probability of presence of the characteristics of interest

$\mathrm{P}=1$, when he adopts

$\mathrm{P}=0$, when he did not adopt.

This model could be explicitly specified thus:

$$
\begin{aligned}
\operatorname{Logit}(P)=\beta_{0} & +\beta_{1} X_{1}+\beta_{2} X_{2}+\beta_{3} X_{3} \\
& +\cdots \ldots \ldots \ldots \ldots \ldots \beta_{n}+n+U_{i}
\end{aligned}
$$

Where $(\mathrm{P})=$ cassava farmers / respondents decision.

$\beta \mathrm{o}=$ intercept term

$\beta_{1}-\beta_{\mathrm{n}}=$ logistic regression coefficient

$\mathrm{X}_{1}-\mathrm{X}_{\mathrm{n}}=$ independent variables

The independent variables are as follows:

$\mathrm{X}_{1}=$ Age (year)

$\mathrm{X}_{2}=$ Educational level (number of years spent in schools.)

$\mathrm{X}_{3}=$ Family size (number)

$\mathrm{X}_{4}=$ Farm size (hectare)

$\mathrm{X}_{5}=$ Farming experience (years)

$\mathrm{X}_{6}=$ Extension contact $(\mathrm{yes}=1$, otherwise $=0)$

$\mathrm{X}_{7}=$ Membership of Association (yes $=1$, otherwise $=0$ )

$\mathrm{X}_{8}=$ Demonstration farm / Agricultural farm visited

$\mathrm{X}_{9}=$ Labour cost measured in man days

$\mathrm{X}_{10}=$ Cassava output (in tonnes)

$\mathrm{X}_{11}=$ Access to credit measured in binary variable. 1 if respondent have access to credit, 0 if otherwise

$\mathrm{X}_{12}=$ Mechanization measured in binary variable. 1 if yes, 0 if otherwise.

$\mathrm{Ui}=$ Error term.

\section{Results and Discussion}

\subsection{Socio-economic Characteristics of Cassava Farmers in the Study Area}

The study revealed that $59.1 \%$ of the respondents were above 50 years old which suggests that young people are not interested in farming again. The result further shows that majority $(85.1 \%)$ were male, $66.9 \%$ were married, $51.9 \%$ had formal education while $48.1 \%$ did not attend any formal school. Majority of the sampled farmers $(66.3 \%)$ took farming as major occupation while $33.7 \%$ work on the farm on part time as they engaged in other jobs like salary job, bricklaying, carpentry, trading, driving and hunting. The most frequent range of total farm size of the respondents was $0.1-0.5$ hectare $(46.4 \%)$ while only $8.3 \%$ had above 2.0 hectares of cassava farm during the study. In having access to agricultural extension services, $50.8 \%$ of the respondents claimed to have access to extension services while $49.2 \%$ did not. Their sources of awareness indicated that majority (37.6\%), got aware of innovation on radio, closely followed by $28.2 \%$ from extension agents and $26.4 \%$ from other farmers who are either colleagues or farm neighbour. The study of adoption level indicated that majority $(55.8 \%)$ had finally adopted, $19.3 \%$ are on trial stage, $7.2 \%$ are still evaluating, $13.8 \%$ had shown interest in knowing more about improved varieties while only $3.9 \%$ said they were truly aware that improved cassava cultivars is available in town. 
Table 1. Analysis of Socio-Economic Variables of the Respondents.

\begin{tabular}{|c|c|c|}
\hline Age & Frequency & Percentage \\
\hline$\leq 30$ & 19 & 10.5 \\
\hline $31-40$ & 34 & 18.8 \\
\hline $41-50$ & 21 & 11.6 \\
\hline $51-60$ & 34 & 18.8 \\
\hline $61-70$ & 38 & 21.5 \\
\hline$>70$ & 34 & 18.8 \\
\hline \multicolumn{3}{|l|}{ Gender } \\
\hline Male & 153 & 85.1 \\
\hline Female & 27 & 14.9 \\
\hline \multicolumn{3}{|l|}{ Marital status } \\
\hline Single & 28 & 15.5 \\
\hline Married & 120 & 66.9 \\
\hline Widowed & 16 & 8.8 \\
\hline Divorced & 16 & 8.8 \\
\hline \multicolumn{3}{|l|}{ Household size } \\
\hline $1-5$ & 72 & 39.8 \\
\hline $6-10$ & 72 & 39.8 \\
\hline $11-15$ & 22 & 12.7 \\
\hline $16-20$ & 14 & 7.7 \\
\hline \multicolumn{3}{|l|}{ Level of Education } \\
\hline No formal education & 86 & 48.1 \\
\hline Primary Education & 28 & 15.5 \\
\hline Secondary Education & 31 & 17.1 \\
\hline University & 17 & 9.4 \\
\hline Others & 18 & 9.9 \\
\hline \multicolumn{3}{|l|}{ Years of Experience } \\
\hline $1-10$ & 71 & 39.2 \\
\hline $11-20$ & 65 & 35.9 \\
\hline $21-30$ & 39 & 22.9 \\
\hline $31-40$ & 5 & 2.8 \\
\hline \multicolumn{3}{|l|}{ Reason cassava production } \\
\hline Food consumption & 114 & 63.5 \\
\hline Easy to cultivate & 29 & 16.1 \\
\hline Industrial usage & 20 & 11.0 \\
\hline For feeding livestock & 2 & 1.1 \\
\hline For raw market sales & 15 & 8.3 \\
\hline \multicolumn{3}{|l|}{ Farm size } \\
\hline $0.1-0.5$ & 83 & 46.4 \\
\hline $0.6-1.0$ & 53 & 29.3 \\
\hline $1.1-1.5$ & 8 & 4.4 \\
\hline $1.6-2.0$ & 21 & 11.6 \\
\hline$>2$ ha & 15 & 8.3 \\
\hline \multicolumn{3}{|l|}{ Access to extension services } \\
\hline No & 89 & 49.2 \\
\hline Yes & 91 & 50.8 \\
\hline \multicolumn{3}{|c|}{ Types of Agricultural Extension Service } \\
\hline No Access to Agric Extension & 90 & 49.7 \\
\hline ADP/Government & 64 & 35.9 \\
\hline Private & 14 & 7.7 \\
\hline Others & 12 & 6.6 \\
\hline \multicolumn{3}{|l|}{ Source of awareness } \\
\hline Extension Agents & 51 & 28.2 \\
\hline Radio & 67 & 37.6 \\
\hline Television & 9 & 5.0 \\
\hline Publication & 5 & 2.8 \\
\hline Other farmers & 48 & 26.4 \\
\hline \multicolumn{3}{|c|}{ Source of Improved cassava cuttings } \\
\hline Research Institute & 6 & 3.4 \\
\hline Extension Agents & 41 & 22.6 \\
\hline Local Governments & 24 & 13.2 \\
\hline Other Farmers & 96 & 53.6 \\
\hline Open Market & 13 & 7.2 \\
\hline
\end{tabular}

\begin{tabular}{lll}
\hline Age & Frequency & Percentage \\
\hline Reasons for planting improved varieties & & \\
Early maturity & 119 & 66.3 \\
Better yield & 49 & 27.2 \\
Disease resistance & 12 & 6.5 \\
\hline
\end{tabular}

Source: Computed from field data, 2016

\subsection{Estimated Binary Logistic Model Results for Farmers' Adoption Model on Selected Socio-economic and Farm Specific Characteristics}

To identify factors which influence the likelihood of adoption of improved cassava planting materials among farmers in the study area, binary logistic model was estimated. $\mathrm{R}^{2}$ for the estimated regression $(0.65)$ is high. This implies that about $65 \%$ of adoption of improved cassava planting material is explained by the explanatory variables. The result further reported that output and farming experience were statistically significant at $1 \%$ while farm size and access to extension services were statistically significant at 5\%. Also, age, level of education and access to credit were statistically significant at $10 \%$. It implies that the statistically significant variables greatly influenced the adoption of improved cassava planting materials in the study area. The positively correlated variables imply that as these variables increase, the higher the adoption of improved cassava planting materials and vice-versa. This was in agreement with earlier studies $[9 ; 10]$ that literacy level positively influenced the intensity of use of fertilizer technology in southwestern Nigeria.

Table 2. Estimated Binary Logistic Model Results for Farmer Adoption Model on Selected Socio Economics and Farm Specific Characteristics.

\begin{tabular}{llll}
\hline Adoption & $\begin{array}{l}\text { Logit } \\
\text { Coefficient }\end{array}$ & $\begin{array}{l}\text { Standard } \\
\text { Error }\end{array}$ & z \\
\hline Age & $0.599^{*}$ & 0.2796 & 2.1438 \\
Educational level & $0.0386^{*}$ & 0.0179 & 2.1564 \\
Household Size & 0.0722 & 0.3151 & 0.2291 \\
Farm Size & $-0.6724^{* *}$ & 0.2963 & -2.2701 \\
Cost of Labour & 0.2902 & 0.3388 & 0.8566 \\
Output & $0.0041^{* * *}$ & 0.0012 & 3.4166 \\
Farming Experience & $0.3033^{* * *}$ & 0.1128 & 2.6881 \\
Access to Extension Service & $0.2382^{* *}$ & 0.0982 & 2.4260 \\
Membership of Association & 0.1620 & 0.4109 & 0.3957 \\
Demonstration farm & -0.3301 & 0.3934 & -0.8391 \\
Access to Credit & $0.7807^{*}$ & 0.3682 & 2.1203 \\
Mechanization & 0.1344 & 0.4357 & 0.3085 \\
Constant & -1.8922 & 2.5479 & -0.7427 \\
Log Likelihood & -99.727 & & \\
$\mathrm{R}^{2}$ & 0.6546 & & \\
\hline
\end{tabular}

Note: $* * *$ and $* * *$ are statistically significant at 10,5 and $1 \%$ respectively Source: Computed from field data, 2016

\subsection{Constraints Facing Cassava Production in the Study Area}

Table 3 presents various problems militating against efficient production of cassava in the study area. It shows that $23.8 \%$ of the sampled farmers had the problem of pests and diseases, $8.8 \%$ complained of low extension contacts as an impediment to optimal production, $16.6 \%$ had the constraints 
of high cost of inputs while $34.2 \%$ which is the highest said insufficient farms labour is their major challenge to production. $10 \%$ complained of lack of fund/credit to finance their farm operations $5.0 \%$ had marketing problem while only $1.1 \%$ complained of transportation problem while the remaining $0.6 \%$ complained about bad weather as impediment to cassava production.

Table 3. Major Problems to Efficiency in Cassava Production.

\begin{tabular}{lll}
\hline Problem & Frequency & Percentage \\
\hline Insufficient Labour & 61 & 34.2 \\
Pest and diseases & 43 & 23.8 \\
Low Extension Contacts & 16 & 8.8 \\
High Cost of Labour & 30 & 16.6 \\
Lack of Credit & 18 & 10.0 \\
Marketing & 9 & 5.0 \\
Transportation problem & 2 & 1.1 \\
Bad Weather & 1 & 0.6 \\
Total & 180 & 100.0 \\
\hline
\end{tabular}

Source: Field Survey, 2016.

\section{Conclusion and Recommendations}

These results clearly show that both socio - economic variables (farm and farmer specific factors) and the perceptions of farmer's specific attributes of improved planting materials determine their observed adoption decisions. This paper further confirms various reported conclusions in adoption and diffusion literature about how socio - economic variables significantly influence adoption decisions of agricultural technologies and particularly the conclusions of [11] that farmer's perceptions of the specific characteristics of new technologies were the major factors conditioning adoption behaviors. It is therefore recommended that government should develop an appropriate frame work to educate the farmers more on the need to adopt improve planting materials to enhance better productivity, agricultural inputs should be highly subsidized, government should introduce "buy back programme" to buy produce from farmer to avoid wastage due to glut which discourage many farmers from embarking on large scale production, the use of modern agricultural implement should be provided for the farmers to supplement crude implements that yield low - returns. This will reduce the problem of labour constraints which is one of the major constraints faced by the peasant farmers, more channels of increased credit should be opened to farmers with less stringent conditions attached. In light of this, there is need to link farmers to formal sources of credit, given its importance in the adoption of improved technologies, necessary infrastructure should be provided by the government in the rural areas so as to avoid rural - urban migration; hence the youth would be encouraged to participate actively in farming and the government at all levels should strengthened the activities of agricultural extension service of the Agricultural Development Programme as it was when world bank was sponsoring the project to ensure that agricultural innovations get to end users (farmers) and encourage to adopt same. In this case, both access to extension service and frequency of contact between extension staff and farmers should be strengthened.

\section{References}

[1] Adeyinka, B. B. (2006): Some Strategies for the Development of Nigeria Agricultural Sector in modern days. Economics and Financial Review, CBN vol. 41 No 11, June 2006, PP 71 - 84.

[2] Ezedinma, T., Polson, R. A. and Spencer, D. S. (2006): The Technology Adoption Process in Subsistence Agriculture: the case of cassava in South Western Nigeria. Agricultural Systems. 35 (1): 65-77.

[3] Central Bank of Nigeria (2002): Annual Reports. Performances of Agriculture on Gross Domestic Products (GDP). Vol. 2 manual series 0014. CBN. Pp 7-12.

[4] Cock, A. R. (2005): The Technology Adoption in Subsistence in South Western Nigeria. Agricultural System, 36 (1).

[5] Mahmoud A. P. (2006): Sustainable cassava production in Nigeria: Farmers Technology Adoption in Relation to Socio Economic Factors. Agricultural system 37, pp 183-192.

[6] Dalton, N. and Guei, T. (2003): Presidential Initiative on Cassava Production in Nigeria 14 - 16 June, 2003.

[7] Dixon, A. O. (2008): Article publication of Tobit Analysis of Agricultural Innovation: A study on fertilizer application among Nigerian cassava farmers. Oxford Agrarian studies 14; $26-51$.

[8] Adeniran, O. A. (2003): "It's all about Ekiti" Creation, Politics and Development of Ekiti State. Published by Babalogbon Printing Press, Ado - Ekiti, pg 14-15.

[9] Feeder, G. Just R., Ziberman D. (2004): Adoption of Agricultural Innovations in developing countries: A survey. Economic Development and Cultural Change 33: 255-298.

[10] Awe, D. A. (1999). Soil fertility management using organic fertilizers and low-external-input techniques in southwestern Nigeria. Paper presented at a National Workshop on Soil Conservation and Soil Management for Sustainable Rural Development in Nigeria, Ibadan 5th -7 th November.

[11] Adesina, A. A. and Zinnah, M. M. (2006): Technology Characteristics, Farmers Perception and Adoption Decisions: I. A. Tobit model application in Sierra Leone. Agricultural Economics (1992) Pp 17-23. 